\title{
Analysis of Kangmei Pharmaceutical's Financial Restatement Behavior from the Perspective of Corporate Governance
}

\author{
Guanglu Xue ${ }^{1}$ \\ ${ }^{1}$ Department of Economics and Management, Guangzhou University Sontan College, Guangzhou, China
}

\begin{abstract}
The object is Kangmei Pharmaceutical, a listed company in the pharmaceutical sector. The research is based on corporate governance, the company's financial restatement behavior is analyzed based on the four aspects of Kangmei Pharmaceutical's equity structure, institutional investors, independent audit institutions, media and regulatory agencies. In order to avoid Kangmei Pharmaceutical's adjustments, several countermeasures and suggestions are put forward, and improve the corporate governance theory of the capital market.
\end{abstract}

\section{Foreword}

On April 30, 2019, ST Kangmei's cash counterfeit case was suddenly disclosed, which surprised the whole industry. ST Kangmei is the current stock name of Kangmei Pharmaceutical Co., Ltd. (hereinafter referred to as Kangmei Pharmaceutical). On December 28, 2018, China Securities Regulatory Commission issued an Investigation Notice, and it placed a case on file for investigation because it was suspected that Kangmei Pharmaceutical illegally disclosed its information. Afterwards, Kangmei Pharmaceutical modified the illegally disclosed financial information, i.e. made financial restatement. According to document principles of accounting information disclosure issued by China Securities Regulatory Commission and Ministry of Finance, financial restatement refers to an action that the listed companies modify the financial statements if they are inconsistent with latest laws. The financial statement is an important carrier for listed companies to disclose their accounting information, and it restricts the investment decision making of stakeholders such as investors and creditors. Therefore, the reliability of disclosed financial statements is always highly emphasized by the capital market. The behavior of financial restatement causes low reliability of early accounting information. Along with frequent reporting of financial restatement behavior, it is still regarded as a difficulty of global investors, and it restricts financing market allocation. The deficiency of enterprise governance is an important factor which causes financial restatement behavior, so the provision of good accounting information is a guarantee to improve enterprise governance mechanism. Therefore, it is significant in theory and application guidance to take Kangmei Pharmaceutical as the research object on the basis of the theory of enterprise governance, research its financial restatement behavior and bind listed companies to provide accurate financial statements.

\section{The background of Kangmei Pharmaceutical financial restatements}

\subsection{Brief information of Kangmei Pharmaceutical}

In July 1997, Ma Xingtian and Xu Dongjin established Puning Kangmei Industrial Co., Ltd., and it was renamed Kangmei Industrial Investment Holdings Co., Ltd. (Kangmei Investment). Ma Xingtian acted as the president. After the development for a long time, the couple established Guangdong Kangmei Pharmaceutical Co., Ltd.(Kangmei Pharmaceutical) together with two legal entities and natural persons. The stock ownership of Kangmei Pharmaceutical changes for many times. Kangmei Investment becomes the shareholder of Kangmei Pharmaceutical's control shares. Ma Xingtian owns $99.68 \%$ of Kangmei Investment's stock ownership, so he is the real actual shareholder. The February in 2001 witnessed Kangmei Pharmaceutical's initial public offering in Shanghai Stock Exchange at first, which marks that the company is formally listed. Kangmei Pharmaceutical focuses on traditional Chinese medicines prepared in ready-to-use forms, and its business involves all parts of the industrial chain of traditional Chinese medicine, including medicinal material planting, research \& development and production and sale service. According to Kangmei Pharmaceutical's statements and reports in 2018, 154 companies are incorporated into the merge of its balance sheets. The additional merged companies in the balance sheet this year amount to 46, including 33 new companies and 13 companies not controlled by the same company.

As the president of Kangmei Investment, Ma Xingtian owns more than one third of Kangmei Pharmaceutical's 
stock ownership, and the proportion of other shareholders' share is small, which indicates that the concentration of Kangmei Pharmaceutical's stock ownership is high. Kangmei Pharmaceutical sets up an internal auditing department, and its external auditor is GP Certified Public Accountants (hereinafter referred to as GP CPA). In December 2018, China Securities Regulatory Commission placed a case on file for investigation of Kangmei Pharmaceutical. On April 28, 2019, GP CPA still issued an auditing report with reservation for Kangmei Pharmaceutical for three reasons including China Securities Regulatory Commission's investigation items, affiliated parties' capital transaction and incomplete financial information of subsidiaries in projects under construction. On April 30, 2019, Kangmei Pharmaceutical issued a series of announcements. Among them, the accounting error modification announcement declares the account and the actuality are inconsistent in Kangmei Pharmaceutical's operating revenue, costs, expenses and receivables and payments before 2018 , and it adjusted the data of the annual report in $2017^{[1]}$. The occurrence of Kangmei Pharmaceutical's financial restatement behavior further reveals the drawbacks of the internal governance in the company, and also reflects the failure of GP CPA as the third-party independent auditor in external governance.

\subsection{Background of Kangmei Pharmaceutical's financial restatement}

Kangmei Parmaceutical's financial restatement behavior is specified with time, mark and content according to the sequence of time, as shown in Table 1.

Table 1 Background of Kangmei Pharmaceutical's financial restatement behavior

\begin{tabular}{|c|c|c|}
\hline Time & Mark & Content \\
\hline $\begin{array}{l}2018.12 .2 \\
8\end{array}$ & Investigation Notice & $\begin{array}{l}\text { China Securities Regulatory Commission placed a case on file for } \\
\text { investigation of Kangmei Pharmaceutical because it violated relevant } \\
\text { regulations of information disclosure. }\end{array}$ \\
\hline 2019.4.30 & $\begin{array}{l}\text { Kangmei } \\
\text { Pharmaceutical issued a } \\
\text { financial restatement of } \\
\text { accounting error which } \\
\text { is about } 30 \text { billion. }\end{array}$ & $\begin{array}{l}\text { Through self-examination and check in the company, the accounts and } \\
\text { the actuality were inconsistent in Kangmei Pharmaceutical's operating } \\
\text { revenue, costs and receivables and payments before } 2018 \text {. The financial } \\
\text { statement in } 2017 \text { was restated. "The procurement payment, project } \\
\text { payment and accounting errors when affirming the business payment } \\
\text { caused an undercount of } 641.07322234 \text { million yuan in company's } \\
\text { receivables, an undercount of } 19.54634994099 \text { billion yuan in the stock, } \\
\text { an undercount of } 631.60010835 \text { million yuan in projects under } \\
\text { construction, and the error caused an overcount of } 29.94430982145 \\
\text { billion yuan when the company checked the account funds". }{ }^{[1]}\end{array}$ \\
\hline 2019.5.17 & $\begin{array}{l}\text { China Securities } \\
\text { Regulatory Commission } \\
\text { revealed the } \\
\text { investigation progress } \\
\text { of Kangmei } \\
\text { Pharmaceutical's case }\end{array}$ & $\begin{array}{l}\text { It is preliminarily investigated that the financial report disclosed by } \\
\text { Kangmei Pharmaceutical between } 2016 \text { and } 2018 \text { is suspected to violate } \\
\text { relevant regulations of Securities Law. }\end{array}$ \\
\hline 2019.5.21 & ST Kangmei & $\begin{array}{l}\text { Kangmei Pharmaceutical implemented risk warning, the abbreviation of } \\
\text { its stock name is ST Kangmei. }\end{array}$ \\
\hline 2019.8.16 & $\begin{array}{l}\text { China Securities } \\
\text { Regulatory Commission } \\
\text { penalized and } \\
\text { publicized Kangmei } \\
\text { Pharmaceutical }\end{array}$ & $\begin{array}{l}\text { China Securities Regulatory Commission sharply pointed out that ST } \\
\text { Kangmei intentionally and systematically conducted financial fraud in a } \\
\text { long time in an organized way, maliciously deceived investors, caused a } \\
\text { bad influence and serious consequence. China Securities Regulatory } \\
\text { Commission has sent the ex-ante notice to parties involved, planned to } \\
\text { impose administrative penalty to Kangmei Pharmaceutical and } 22 \\
\text { persons concerned including Ma Xingtian, and forbade } 6 \text { persons } \\
\text { concerned to get access to the security market. The actual controllers } \\
\text { including Ma Xingtian and Xu Dongjin were forbidden to get access to } \\
\text { the security market for all their life, and the top punishment was imposed } \\
\text { to them. }{ }^{[2]}\end{array}$ \\
\hline
\end{tabular}

Note: relevant contents are organized and collected from the internet and annual reports issued by Kangmei Pharmaceutical.

\section{Analysis about Kangmei Pharmaceutical's financial restatement}

\subsection{Stock ownership structure}

As shown in Table 2, the proportion of shares held by the first shareholder (Kangmei Investment) in Kangmei Pharmaceutical is about $32 \%$, and the second structure stock holding proportion is $5.27 \%$, and the third structure stock holding proportion is $3.29 \%$. The structure stock holding proportion of the first shareholder is about $18 \%$ higher than the total amount of the other shareholders. The structure stock holding proportion of Ma Xingtian and his wife is $34.41 \%$, and the total proportion of the other shareholders' structure stock holding is far lower than the total proportion of the couple. Therefore, Kangmei Pharmaceutical's stock ownership is mostly concentrated in the large shareholders. The concentration of stock ownership is high, and the ownership of the other 
shareholders' ownership is low. It is very scattering. Kangmei Pharmaceutical is a listed company with high concentration of stock ownership.

Table 2 Stock ownership statistics of Kangmei Pharmaceutical between 2016 and the end of 2019

\begin{tabular}{|c|c|c|c|c|c|c|c|}
\hline \multirow[b]{2}{*}{ Year } & \multicolumn{5}{|c|}{ Holding proportion of the top 5 floating stocks (\%) } & \multirow{2}{*}{$\begin{array}{l}\text { Total stock } \\
\text { holding } \\
\text { proportion of the } \\
\text { second-fifth } \\
\text { shareholders }\end{array}$} & \multirow[b]{2}{*}{$\begin{array}{l}\text { Equity } \\
\text { restriction }\end{array}$} \\
\hline & $\begin{array}{l}\text { The first } \\
\text { shareholder }\end{array}$ & $\begin{array}{l}\text { The second } \\
\text { shareholder }\end{array}$ & $\begin{array}{l}\text { The third } \\
\text { shareholder }\end{array}$ & $\begin{array}{l}\text { The fourth } \\
\text { shareholder }\end{array}$ & $\begin{array}{l}\text { The fifth } \\
\text { shareholder }\end{array}$ & & \\
\hline 2016 & 30.42 & 5.22 & 3.31 & 1.55 & 2.17 & 12.25 & 0.402696 \\
\hline 2017 & 32.50 & 5.27 & 3.29 & 3.70 & 2.22 & 14.48 & 0.445538 \\
\hline 2018 & 32.42 & 5.27 & 3.29 & 3.04 & 2.22 & 13.82 & 0.426280 \\
\hline 2019.9.30 & 32.19 & 5.26 & 3.29 & 2.73 & 2.22 & 13.50 & 0.419385 \\
\hline
\end{tabular}

Data source: organized from Straight Flush.

Before the financial restatement of Kangmei Pharmaceutical, Kangmei Investment remains its first shareholder, and its holding stock always accounts for about $32 \%$. The stock holding proportion is small, which is less than $5 \%$, and the concentration of stock ownership is scattering. It can also be verified from the index of equity restriction. It is apparent in Table 1 that the equity restriction value in four periods is about 0.42 , indicating that the small shareholders cannot restrict the large shareholder, or the restriction effect is not apparent. The equity restriction and financial restatement change inversely. Especially in 2016, the lowest value of equity restriction system in the list is merely 0.402696 . Therefore, Kangmei Pharmaceutical's low equity restriction is also an important reason of financial restatement in 2016, 2017 and 2018.

On May 17, 2018, Kangmei Pharmaceutical invited 35 interested shareholders and agents to hold 2017 shareholders meeting. The voting was conducted on site and via internet. The voting right representing Kangmei Pharmaceutical 2111606082 stock accounted for $42.4507 \%$ of the overall stock ownership. Ma Xingtian owned 1.637 voting right stock, accounting for $77.5239 \%$ of voting right stock. According to the financial data after restatement in 2017, Kangmei Pharmaceutical falsely increased its monetary fund by 29.944 billion yuan. It shows that it is amazing that the large shareholders misappropriate the interests of listed companies, and the amount is enormous, which seriously impairs the interests of medium and small shareholders. Under the governance of stock ownership structure which is dominated by Ma Xingtian, Kangmei Pharmaceutical acted arbitrarily to adopt a series of relevant proposals although there was false reporting in its financial data in 2017. From the final results of the shareholders meeting, Ma Xingtian fully manipulates the shareholder meeting, makes decisions that are consistent with his own interests according to his personal will. The interests of small shareholders are continuously impaired, and institutional investors also cannot effectively supervise Kangmei Pharmaceutical. The high concentration of stock ownership structure causes serious drawback of Kangmei Pharmaceutical's company governance, and the company governance fails.

\subsection{Institutional investors}

From the stock holding proportion, it is indicated in Table 3 that among top ten shareholders' stock in Kangmei Pharmaceutical in the end of 2018, the stock holding proportion of institutional investors is low, the stock holding proportion of Minmetals International Trust Co., Ltd. is $4.66 \%$ among top ten shareholders, and the proportion of China International Capital Corporation Limited is $2.99 \%$. Considering the cost benefit, the exit cost and the stock holding quantity positively change. Therefore, the larger the institutional investors' stock holding is, the more actively the institutional investors will make supervision. If the smaller the stock holding proportion of the institutional investors is, the less actively the institutional investors will make supervision. From the stock type, three companies own restricted floating stock, including stock holding companies, mainly because the stock holding proportion of most investors is small and their activity of supervising Kangmei Pharmaceutical is bad due to pledge of stock rights.

Table 3 the stock holding of Kangmei Pharmaceutical's top ten shareholders at the end of 2018

\begin{tabular}{cccccc}
\hline $\begin{array}{c}\text { Institution or fund } \\
\text { name }\end{array}$ & Abbreviation & Stock type & $\begin{array}{c}\text { Stock holding } \\
\text { proportion (\%) }\end{array}$ & $\begin{array}{c}\text { Stock holding } \\
\text { quantity (share) }\end{array}$ & $\begin{array}{c}\text { Stock holding } \\
\text { change (share) }\end{array}$ \\
\hline $\begin{array}{c}\text { Kangmei Industrial } \\
\text { Investment Holding Co., } \\
\text { Ltd. }\end{array}$ & $\begin{array}{c}\text { Kangmei } \\
\text { Investment }\end{array}$ & $\begin{array}{c}\text { Restricted } \\
\text { floating stock, } \\
\text { circulating A }\end{array}$ & 32.91 & 1.637 billion & $\begin{array}{c}-2.9789 \\
\text { million }\end{array}$ \\
$\begin{array}{c}\text { Minmetals } \\
\begin{array}{c}\text { International Trust Co., } \\
\text { Ltd. }\end{array}\end{array}$ & $\begin{array}{c}\text { Minmetals } \\
\text { International } \\
\text { Trust Co., }\end{array}$ & $\begin{array}{c}\text { Circulating A } \\
\text { share }\end{array}$ & 4.66 & 0.232 billion & unchanged \\
\hline
\end{tabular}




\begin{tabular}{|c|c|c|c|c|c|}
\hline \multicolumn{4}{|c|}{ Ltd. } & \multirow[b]{2}{*}{0.164 billion } & \multirow[b]{2}{*}{ unchanged } \\
\hline $\begin{array}{c}\text { Shenzhen Qianhai } \\
\text { Chongmingwanfang } \\
\text { Equity Investment Co., } \\
\text { Ltd. }\end{array}$ & $\begin{array}{l}\text { Chongmingw } \\
\text { anfang }\end{array}$ & $\begin{array}{c}\text { Restricted } \\
\text { floating stock }\end{array}$ & 3.29 & & \\
\hline $\begin{array}{c}\text { China Securities } \\
\text { Finance Corporation } \\
\text { Limited }\end{array}$ & CICC & $\begin{array}{l}\text { Circulating A } \\
\text { share }\end{array}$ & 2.99 & 0.149 billion & unchanged \\
\hline $\begin{array}{c}\text { Changzhou } \\
\text { Yanzeyonghui } \\
\text { Investment Center }\end{array}$ & $\begin{array}{l}\text { Yanzeyonghu } \\
\mathrm{i}\end{array}$ & $\begin{array}{l}\text { Circulating A } \\
\text { share }\end{array}$ & 2.69 & 0.134 billion & -3.032 million \\
\hline $\begin{array}{c}\text { Tianjin } \\
\text { Kunpengrongchuang } \\
\text { Enterprise } \\
\text { Management } \\
\text { Consulting Co., Ltd. }\end{array}$ & $\begin{array}{l}\text { Kunpengrong } \\
\text { chuang }\end{array}$ & $\begin{array}{c}\text { Restricted } \\
\text { floating stock }\end{array}$ & 1.97 & 98.1675 million & unchanged \\
\hline Xu Dongjin & $\mathrm{Xu}$ Dongjin & $\begin{array}{c}\text { Circulating A } \\
\text { share }\end{array}$ & 1.97 & 97.8037 million & unchanged \\
\hline $\begin{array}{c}\text { Puning } \\
\text { Jinxindiandanghang } \\
\text { Co., Ltd. }\end{array}$ & $\begin{array}{c}\text { Jinxindiandan } \\
\mathrm{g}\end{array}$ & $\begin{array}{l}\text { Circulating A } \\
\text { share }\end{array}$ & 1.87 & 93.1147 million & unchanged \\
\hline $\begin{array}{l}\text { Puning International } \\
\text { Information Consulting } \\
\text { Service Co., Ltd. }\end{array}$ & $\begin{array}{c}\text { Puning } \\
\text { International }\end{array}$ & $\begin{array}{c}\text { Circulating A } \\
\text { share }\end{array}$ & 1.87 & 93.1147 million & unchanged \\
\hline Chen Shuxiong & $\begin{array}{c}\text { Chen } \\
\text { Shuxiong }\end{array}$ & $\begin{array}{c}\text { Circulating A } \\
\text { share }\end{array}$ & 1.59 & 78.8823 million & $\begin{array}{c}-8.6144 \\
\text { million }\end{array}$ \\
\hline
\end{tabular}

Data source: Straight Flush

From the change in shareholding, Chen Shuxiong's reduced share amount is the largest, which are 8.6144 million shares. Yanzeyonghui decreased 3.032 million shares, and Kangmei Investment decreased 2.9789 million shares. It is indicated that the adverse market news happens to Kangmei Pharmaceutical. Investors decrease shares in order to obtain short-term investment benefits. On the other hand, Kangmei Pharmaceutical's institutional investors cannot dispatch representatives into the company's board of directors, and they cannot restrict Kangmei Pharmaceutical's internal controllers through the board of directors, so they cannot play the role of governance for the company's major decisions.

From the shareholding time, Kangmei Pharmaceutical was jointly established by Kangmei Investment, Jinxindiandang, Puning International and $\mathrm{Xu}$ Dongjin (person in charge in the board of supervisors) at the beginning of establishment. They have held the company's shares since its establishment. The above individual and legal entities mutually hold the shares of each other. Therefore, in this stock ownership structure (family type), the internal company governance cannot play its role. Minmetals International Trust Co., Ltd., Chongmingwanfang, CICC and Yanzeyonghui did not hold the shares of Kangmei Pharmaceutical until 2016. That is to say, they purchased the shares three years before the financial restatement of Kangmei Pharmaceutical. Generally speaking, investors' activity of supervising listed companies is related to their stock holding time, and it is important in the company governance structure. Apparently, these four institutional investors do not hold Kangmei's shares for a long time, so their supervision activity and position are not apparent, and they do not play the role of their own active governance.

\subsection{External independent auditing}

From the beginning of being listed to the occurrence of financial restatement, GP CPA has acted as its external independent auditor. It has provided Kangmei Pharmaceutical with external auditing business for 19 years. It issued 18 auditing reports, including 17 standard auditing reports. After Kangmei Pharmaceutical was investigated by China Securities Regulatory Commission, GP CPA still issued auditing comments with reservations. The independent auditing institution fails to play the role of external supervision. This is an important reason for Kangmei Pharmaceutical's financial restatement.

\subsubsection{Accounting firm's negligence of duty}

Kangmei Pharmaceutical's major accounting error and financial restatement result from GP CPA' negligence of duty. According to Kangmei Pharmaceutical's restated data of financial statement in 2017, does GP CPA not doubt the authenticity of false increased monetary fund for about 30 billion? For professionals who engage in auditing, the auditing procedures of bank deposit letters must be adopted, and the auditing evidence must be formed. If they are not adopted, the auditing institutions may forge information together with the company, but GP CPA' reply letter to Shanghai Stock Exchange declares that Kangmei does not provide auditing evidences. There may exist another seemingly impossible case that Kangmei Pharmaceutical forges the accounting evidences such as back bills and confirmation requests. The project payment for 3.6 billion yuan does not enter into the account book according to Kangmei Pharmaceutical's annual report in 2018. As an external independent auditor, GP CPA shall 
have found this fact through on-site judgment of relevant project budget and completion schedule, but it does not disclose this fact. It can be judged that GP CPA fails to fulfill its obligation in auditing. GP CPA' failure to perform the responsibility of independent auditing provides an opportunity for Kangmei Pharmaceutical to forge evidences.

On May 28, 2019, Kangmei Pharmaceutical modified its previous remarks and declared to trace and adjust the annual reports in two years before 2018. The traced and adjusted payment mainly involves procurement payment, stock and payment of projects under construction. Among them, the annual report in 2016 is traced and adjusted as follows: adjust and increase 17.934 billion yuan of the stock (traditional Chinese medicinal materials) that did not enter into the account book; adjust and increase 0.855 billion yuan of the stock (development cost) that did not enter into the account book; adjust and increase 0.279 billion yuan of projects under construction that did not enter into the account book. The annual report in 2017 is traced and adjusted as follows: adjust and increase 0.409 billion yuan of the stock that did not enter into the account book; adjust and increase 0.949 billion yuan of the stock (development cost) that did not enter into the account book; adjust and increase 0.353 billion yuan of projects under construction that did not enter into the account book. The amount of payment involving stock and projects under construction in 2016 is 19 billion-yuan, accounting for about $35 \%$ in the total assets. When there are some major errors in projects under construction and stock, it can be known that there are large financial risks in the company's annual reports. GP CPA' dereliction of independent auditing duty foreshadows the serious accounting errors in Kangmei Pharmaceutical's financial statement. The standard auditing reports issued in GP CPA conceal Kangmei Pharmaceutical's false statement. This is also an important reason for Kangmei Pharmaceutical's financial restatement later. Therefore, GP CPA lacks professional auditing ability, so its independent auditing is not rigorous, and it cannot make effective supervision of external governance.

\subsubsection{Auditors}

7 certified accountants signed the auditing reports according to 18 auditing reports issued by Kangmei Pharmaceutical. Among them, Yang Wenwei signed the name for 12 times, He Guoquan signed the name for 11 times, Ji Zhengxiong signed the name for 5 times, Zhang Jingli signed the name for 5 times, Xiong Yongzhong, Liu Huowang and Liu Qing signed the names once respectively. Yang Wenwei is entirely worn out in performing the duties for Kangmei Pharmaceutical's being listed and providing auditing reports. He is also the legal representative of GP $\mathrm{CPA}$ and a member of Issuance Appraisal Committee in Second-board Market of China Securities Regulatory Commission. Ji Zhengxiong's qualification and experience are similar to those of Yang Wenwei. He also acts as the director in many companies. $\mathrm{He}$ is famous in the capital auditing field in Guangdong. This indicates his position in the auditing field. In the long-term business cooperation, certified accountants do not make objective assessment according to real accounting evidences, and they make assessment and provide auditing comments according to their own subjective judgment and Kangmei Pharmaceutical's selfexamination information, which leads to low-quality auditing.

Another reason for low-quality auditing is the economic interests. At the beginning of being listed, GP CPA obtained the auditing award for about 0.3 million yuan each year. The year 2009 is an important watershed. GP CPA' auditing awards boom, which is more than 1 million yuan, and it is steadily increasing every year. In 2013, GP CPA concurrently acted as the internal auditor of Kangmei Pharmaceutical, obtained an award of 3.7 million yuan. The total award is 6.4 million yuan by 2018 . Motivated by interests, auditors cannot implement independent auditing so that the external company governance fails.

\subsubsection{Auditing comment}

The auditing comment reflects accountant firm's external governance of listed companies, and it is an important media of external governance. Among 18 auditing reports issued by GP CPA, 17 reports are standard auditing comments without reservation. One report is an auditing comment with reservation when Kangmei Pharmaceutical's financial restatement occurred. On April 30, 2019, the 2018 internal auditing report issued by GP CPA claimed that there were major defects in Kangmei Pharmaceutical's fund management, related transaction and financial accounting, which led to early accounting error modification. Except the auditing report with reservation for stated items in Kangmei Pharmaceutical's 2018 financial statement, it is not found that the company's early accounting error modification is improper ${ }^{[1]}$. The standard auditing report issued by GP CPA claims that Kangmei Pharmaceutical's annual reports in 2016 and 2017 truly reflect the company's financial status, and Kangmei Pharmaceutical insists in tracing and adjusting the financial statements in the previous two years. Are these two actions contradictory? GP CPA aims to show that Kangmei Pharmaceutical forges bills which do not merely involve simple accounting, but Kangmei Pharmaceutical's whole financial statements are seriously counterfeit. The traced and adjusted asset item for 29.9 billion yuan nearly accounts for half of the total asset. For such a major "accounting error", GP CPA does not modify the auditing comments for the auditing reports in the previous two years, but always reaffirms modification of accounting errors. It does not doubt other tracing and adjustment. Whether is it proven that GP CPA cannot help but to seize the final life-saving opportunity? The auditing comments issued by GP CPA can make improvements for Kangmei Pharmaceutical, but we are still doubtful for the independence of the accountant firm and the eligibility of auditors is uncertain. 


\subsection{Media and regulatory authorities}

The media plays an active governance role in Kangmei Pharmaceutical's financial restatement behavior. On October 22, 2018, Diyicaijing's journalist wrote an article called The truth of Kangmei Pharmaceutical's collapse: mysterious trader was arrested two weeks ago? and it pointed out that the directors working in Kangmei Pharmaceutical for many years adopted insider trading and manipulated stock prices together with Xu Dongjin, and the public security agency had allowed it to obtain a guarantor and awaited trial out of custody. Through reporting by the media, Kangmei Pharmaceutical's stock price continuously collapsed from 21.88 yuan/stock to 10.34 yuan/stock, a decrease of $111.6 \%$. The market value loses more than 80 billion yuan, approximates to half of the market value. The pressure from the media opinion forces Kangmei Pharmaceutical to provide high-quality and reliable financial information. Due to the attention and disclosure of the media, the media supervision of Kangmei Pharmaceutical's external governance is strengthened.

The information of external governance is usually obtained late, so the external governance institutions mostly play the role of ex post facto governance. After it is disclosed that Kangmei Pharmaceutical forges information, the ex post facto governance can drive Kangmei Pharmaceutical to implement financial restatement, strengthen the reliability of financial information, and prevent investors from making improper investment plans with false financial information so as to bring irreparable loss to investors. Therefore, the media agencies strengthen reporting of the financial information in the capital market in advance, and the regulatory authorities strengthen disclosure regulations of financial information in the capital market, and improve the restriction mechanism of financial information disclosure.

\section{Inspiration and comments}

In conclusion, the event of cash counterfeit case for about 30 billion yuan in Kangmei Pharmaceutical in 2019 gives us three inspections. At first, the stock ownership is highly concentrated in family members, which reveals the disadvantages of the management mode. Secondly, the financial investors constitute the majority, fail to perform the supervision responsibility, and the activity of participating the operation decision-making is hurt. Thirdly, the independence of the accountant firm is doubtful, and the auditors' eligibility is uncertain. Therefore, the following modification suggestions are proposed in order to avoid recurrence of similar major accounting error modification and financial statement behavior in Kangmei Pharmaceutical and other listed companies.

\subsection{Optimize the stock ownership structure}

In Kangmei Pharmaceutical's stock ownership structure, the concentration of stock ownership is high, which is an important reason for major accounting error and financial restatement behavior. Kangmei Pharmaceutical's largest shareholder Ma Xingtian selects relatives to control the shareholder meeting, nominates and selects directors to manipulate the board of directors, gives out post on grounds of personal favor, appoints his wife as the chairwoman of the board of supervisors so as to manipulate it. Such an internal governance institution is a family type enterprise to some extent. The internal governance structure cannot effectively operate, which leads to its low operation efficiency. Another factor of the internal governance structure is the low restriction of stock ownership. The shareholders' meeting cannot fulfill rights according to the will of shareholders. The board of supervisors also cannot perform the supervision duty. They are led by Ma Xingtian. The internal governance cannot effectively restrict it. The company's internal governance is out of balance. Therefore, there appear problems in Kangmei Pharmaceutical's internal governance, which inevitably causes that the large shareholders seize the interests of small shareholders. The problem of secretly misappropriating the company's interests in the company governance is revealed. Therefore, the internal governance structure shall be sorted out for the capital market at the stage of growth. The large shareholders enjoy the control right and execution right with corresponding responsibility for the company's stock ownership. The board of directors performs the company's major decision-making right, and the board of supervisors performs the supervision right. The company stock ownership structure shall be further optimized, the stock ownership restriction system shall be promoted to form the pattern in which shareholders' authority and responsibility are mutually restricted, avoid one dominating shareholder who seize the rights and interests of small shareholders, and curb the occurrence of financial restatement for listed companies.

\subsection{Actively play the governance role of institutional investors.}

The appearance of financial restatement in Kangmei Pharmaceutical is closely related with institutional investors' active governance. The proportion and duration of stocks held by institutional investors directly affect the efficiency of the company governance. When investors' purchased stock ownership proportion is small and the holding time is short, they aim to earn short-term benefits, which promotes the probability of the company to manipulate the surplus profit, and the investors' governance efficiency is low. When investors' purchased stock ownership proportion is high and the holding time is long, investors pay more attention to the long-term investment benefit. Investors actively dispatch relevant personnel, participate in management of the company's affairs and perform their active governance duty on behalf of them. The strategic investors shall be energetically introduced so as to hold back the recurrence of financial restatement behavior, because they pay attention to the future development blueprint, strategic goals of listed companies so as to obtain long-term investment return. The interests of strategic investors and listed companies are associated. They actively perform governance role, 
encourage listed companies to issue high-quality financial information, supervise the behavior of the company surplus profit manipulation, promote highly efficient governance, and reduce the frequency of the company financial restatement behavior.

\subsection{Strengthen the external function of independent auditing governance}

It can be judged that the auditing of GP CPA fails from Kangmei Pharmaceutical's financial restatement. In case of financial restatement, the obligation performed by the third-party auditing institution is slight, and the cost they pay is low, so the third-party auditing institutions' comments for auditing reports is subjective, and they even attend to a matter negligently. The information of the third-party auditing institutions and listed companies is inconsistent. In addition, the regulatory authorities lack the accountability investigation mechanism for the thirdparty auditing institutions so that the third-party auditing institutions conspire with listed companies, seriously impair the interests of small shareholders and institutional investors, and lose the faith in the securities market. The regulatory authorities further improve legal details of relevant authority and responsibility for independent auditing institutions and personnel, impose penalty for those who violate legal details of authority and responsibility. Especially, once the accounting information error modification occurs to the auditing objects, the "inverse investigation" mechanism of accountability shall be carried out, and it shall be seriously dealt with.

The financial restatement occurred to Kangmei Pharmaceutical in 2018, and the auditing reporting with reservation was issued. The auditing report without reservation was issued for Kangmei Pharmaceutical to trace and adjust 29.944 billion yuan. GP CPA issued two different auditing comments, which indicates that it lacks eligibility and the external auditing institution lacks auditing independence. Therefore, the third-party auditing institution shall strengthen auditing quality control, constantly promote auditors' professional level, strengthen auditors' further education, reform auditing practices, and promote the reliability of auditing comments instead of making up for losses in other ways. In summary, the thirdparty auditing institution shall improve auditing quality, promote auditing professional eligibility, provide financial information users with highly reliable auditing comments $^{[5]}$.

\subsection{Strengthen ex ante supervision and ex post facto punishment}

Shanghai Stock Exchange, Shenzhen Stock Exchange and China Securities Regulatory Commission establish the risk warning mechanism for the capital market, strengthen ex ante supervision. On the one hand, the management institutions adopt dynamic supervision, pay special attention to relevant indicators such as the company finance, operation and governance level, identify whether there exist risks in the indicator values, recognize the risk level, adopt relevant supervision policies, and penalize list companies who violate regulations and laws. Under the pressure of risk warning supervision of regulatory authorities, the accounting information quality is remarkably improved, and the company surplus profit manipulation is held back. This is better for regulatory authorities to monitor and investigate the occurrence of the company false reporting of surplus, and hold back financial restatement of list companies. On the other hand, the media shall be guided and encouraged to supervise the opinions in the capital market. The legitimate rights of the media shall be safeguarded. The good environment shall be created. This is beneficial to arouse the governance role of external media.

Besides, the ex post facto punishment is indispensable. At the beginning, the punishment of denouncement is not strong for listed companies. It may affect listed companies and lower awards in the short term, but its punishment effect for list companies is low. Therefore, the regulatory authorities shall issue more detailed rules on information disclosure of listed companies. According to each rule, the standard and amount of punishment and the time, procedure and goal of subsequent rectification shall be defined. For listed companies that have been publicly denounced and incorporated into the risk early warning system, the supervision shall be strengthened, and the relevant situation of follow-up rectification shall be announced in stages so as to warn the others in the whole capital market. Secondly, the credit system of listed companies shall be established mainly from the financial restatement modification frequency, corporate reputation, bank loan line, government subsidies, a number of indicators shall be subdivided, the index weight shall be given, the total scores can be obtained after comprehensive evaluation. If the comprehensive values of listed companies exceed the warning line, China Securities Regulatory Commission will adopt relevant measures to hold back the occurrence of financial restatement. Finally, the delisted mechanism of listed companies shall be compulsorily observed. The imperfect financial market and opaque laws and regulations cause that the delisted mechanism of the capital market cannot be strictly implemented. If the regulatory authorities strictly implement delisted mechanism, the low financial information will be avoided in the capital market, the comprehensive quality of listed companies will be improved at most. Their financial restatement will be held back. The capital market will vigorously develop.

\section{Reference}

1. Kangmei Pharmaceuticals. kangmei Pharmaceuticals' Announcement on Corrections to Pre-Accounting Errors [EB/OL] .www.kangmei.com.cn, 2019-0430

2. STKangmei.Special Notes on Inquiries on Matters reported by Kangmei Pharmaceutical Co., Ltd. [EB/OL] . www.kangmei.com.cn, 2019-05-29 .

3. STKangmei.Notice of receipt of the Notice of Administrative Penalties and Market Ban// from the 
China Securities Regulatory Commission [EB/OL] .www.cninfo.com.cn, 2019-08-17.

4. Shizhong huang. Analysis on the Extension of Kangmei Pharmaceutical's Financial Fraud. Finance and Accounting monthly,2019(17):3-6+178.

5. Xiayun Song, Bowen Tan. A Case Study of zhongzhong Zhujiang Accounting Firm's audit failure on Kangmei Pharmaceutical. Commercial Accounting, 2019(22):4-8. 